\title{
New hosts of Oidiopsis haplophylli in the Solanaceae Family in Brazil
}

\author{
Ailton Reis ${ }^{1}$, Leonardo S. Boiteux ${ }^{1 *}$, Milton L. Paz-Lima ${ }^{2}$, Patrícia P. Silva1 \& Carlos A. Lopes ${ }^{1}$ \\ 'Embrapa Hortaliças, Cx. Postal 218, CEP 70359-970, Brasília, DF, Brazil, e-mail: boiteux@enph.embrapa.br; \\ ${ }^{2}$ Universidade de Brasília, Depto. Fitopatologia, Cx. Postal 4457, CEP 70910-900, Brasília, DF
}

(Accepted for publication in 12/11/2004)

Corresponding author: Leonardo S. Boiteux

REIS, A., BOITEUX L.S., PAZ-LIMA, M.L., SILVA, P.P. \& LOPES, C.A. New hosts of Oidiopsis haplophylli in the Solanaceae family in Brazil. Fitopatologia Brasileira 30:195-198. 2005.

\begin{abstract}
A powdery mildew disease was observed on leaves of Solanum gilo, S. melongena, S. tuberosum S. chacoense, Nicotiana rustica and N. tabacum in Brasília (Federal District), Brazil. Symptoms were mainly characterized by adaxial yellow areas in the leaves corresponding to white fungal colonies on the abaxial surface. Profuse sporulation was often observed. Light microscopy of the fungal colonies revealed the presence of conidiophores emerging through stomata with some having two or three branches. Ellipsoidal, subhyaline conidia were predominantly born singly and terminally on the conidiophore. All morphometrical characteristics agreed with those of Oidiopsis haplophylli (Syn. O. sicula). The teleomorph (Leveillula taurica) was not observed. Inoculation tests indicated that $O$. haplophylli isolates obtained from $S$. gilo, $S$. melongena, S. tuberosum, S. chacoense, Nicotiana rustica and N. tabacum were also pathogenic to sweet pepper (Capsicum annuum) and tomato (Lycopersicon esculentum). This is apparently the first report of these Solanaceae species as hosts of $O$. haplophylli in Brazil. This disease may become important in these crops, especially in greenhouses, and in hot and dry areas where drip irrigation is employed.

Additional keywords: etiology, Solanum gilo, S. melongena, S. tuberosum, S. chacoense, Nicotiana tabacum, N. rustica, powdery mildew, Leveillula taurica.
\end{abstract}

\section{RESUMO}

Novas solanáceas hospedeiras de Oidiopsis haplophylli no Brasil

A ocorrência natural de oídio foi observada em plantas de jiló (Solanum gilo), berinjela (S. melongena), batata $(S$. tuberosum), batata silvestre (S. chacoense) e em duas espécies de fumo (Nicotiana rustica e N. tabacum) em Brasília, Distrito Federal. Os sintomas iniciais da doença incluíam manchas amarelas na face superior do limbo foliar correspondendo a colônias fúngicas, esbranquiçadas com abundante produção de conídios, na superfície inferior. Com o desenvolvimento da doença, as manchas amarelas passaram a necróticas com coloração marrom clara. Observações em lupa revelaram a presença de conidióforos emergindo através dos estômatos e alguns apresentavam duas a três ramificações. Conídios hialinos e com evidente dimorfismo foram observados, sendo os conídios primários de formato lanceolado e os secundários subcilindricos. As características morfológicas e morfométricas dos dois tipos de conídios apresentaram um padrão similar àqueles descritos para Oidiopsis haplophylli. A forma perfeita do fungo (Leveillula taurica) não foi encontrada em nenhuma das hospedeiras examinadas. Este é o primeiro relato destas seis espécies de solanáceas como hospedeiras naturais de $O$. haplophylli no Brasil. Inoculações controladas empregando os isolados de $O$. haplophylli obtidos destas hospedeiras indicaram que estes são também patogênicos ao pimentão (Capsicum annuum) e tomate (Lycopersicon esculentum). Esta doença pode se tornar um problema para estas novas hospedeiras especialmente em condições de cultivo protegido ou em áreas de clima seco com irrigação localizada via gotejamento.

Palavras-chave adicionais: etiologia, oídio, Leveillula taurica, Oidiopsis sicula, Solanum gilo, S. melongena, S. tuberosum, Nicotiana rustica, N. tabacum.

Many field and vegetable crops of economic importance are members of the Solanaceae family including tobacco (Nicotiana spp.), tomato (Lycopersicon esculentum Mill.), sweet pepper (Capsicum annuum L.), potato (Solanum tuberosum L.), eggplant ( $S$. melongena L.) and gilo ( $S$. gilo Raddi). The genomes of the plant species within the Solanaceae family are highly conserved in relation to chromosome number, gene order, and gene repertoire (Doganlar et al. 2002). Therefore, it is not surprising that a number of common diseases occur in species of this family caused by the same virus, bacteria, nematodes or fungi (Zambolim et al. 2000).

Oidiopsis haplophylli Rulamort (syn. O. sicula Scalia or O. taurica Salmon), is an unusually polyphagous powdery mildew-causing fungus able to infect a broad range of herbaceous plants in different taxa, including several genera and species within the Solanaceae (Palti, 1988; Cook et al. 1997; Mendes et al. 1998). Infection by O. haplophylli may cause economic losses to tomato and sweet pepper during the 
dry season in open-field plantings and during the entire year under greenhouse and/or plastic house conditions. Currently, powdery mildew (PM) caused by $O$. haplophylli is one of the most important fungal diseases affecting tomato and sweet pepper under plastic cultivation in Central Brazil (Café Filho et al. 2001).

Complexes of greenhouses for large-scale commercial production of transplants are now increasing in number and in economic importance in Brazil. A number of distinct species are cultivated in these large contiguous areas. It is common to observe styrofoam trays (used for initial plant cultivation) with seedlings of distinct vegetable species in either the same or in adjacent insect-proof greenhouses. The $O$. haplophylli spores are not trapped in the nets used in these seedling producing greenhouses and a relatively large number of plant species naturally affected by this disease has been observed in greenhouses located in Brasília (Distrito Federal). The PM symptoms in those plants were mainly characterized by yellow spots on the upper leaf surface corresponding to fungal colonies in the abaxial surface with profuse sporulation. These symptoms were very similar to those formerly described as being caused by $O$. haplophylli in tomato and sweet pepper (Boiteux et al. 1994; Santos \& Boiteux, 1994; Liberato et al. 1998; 2000). However, similar PM symptoms were observed in several plant species previously not described as being hosts of $O$. haplophylli in Brazil. In this work, we describe for the first time, the occurrence of PM on six species of two genera in the family Solanaceae, and provide the identification of the causal agent.

Greenhouse-grown seedlings of potato, wild potato $(S$. chacoense Bitter) eggplant, gilo and two tobacco species ( $N$. tabacum L. and $N$. rustica L.) were observed exhibiting typical PM symptoms (Figure 1- A to C). Eggplant and gilo leaves with PM symptoms were also found in experimental fields of Embrapa Hortaliças in Brasilia. Light microscopy of the fungal colonies on all these hosts revealed the presence of conidiophores emerging through leaf stomata. Some conidiophores were divided into two to three branches. Ellipsoidal, light-pale conidia were predominantly borne singly and terminally on the conidiophores (Figure 1-E). The major light microscopy and host range characteristics were in complete agreement with an $O$. haplophylli-induced PM disease as described in the synoptic table elaborated by Cook et al. (1997) including: large size lanceolate shaped primary conidia and secondary conidia with a somewhat cylindrical shape (Figure 1-D), absence of fibrosin bodies, conidia formed singly (not in chains), presence of only endophytic mycelium, appressoria not lobed and able to infect a large number of herbaceous hosts. Sexual stage [Leveillula taurica (Lev) Arnald] was not observed in any host plant throughout the present investigation.

Measurements of length and diameter were performed using 30 primary conidia and 30 secondary conidia (chosen randomly) collected from each host described in this
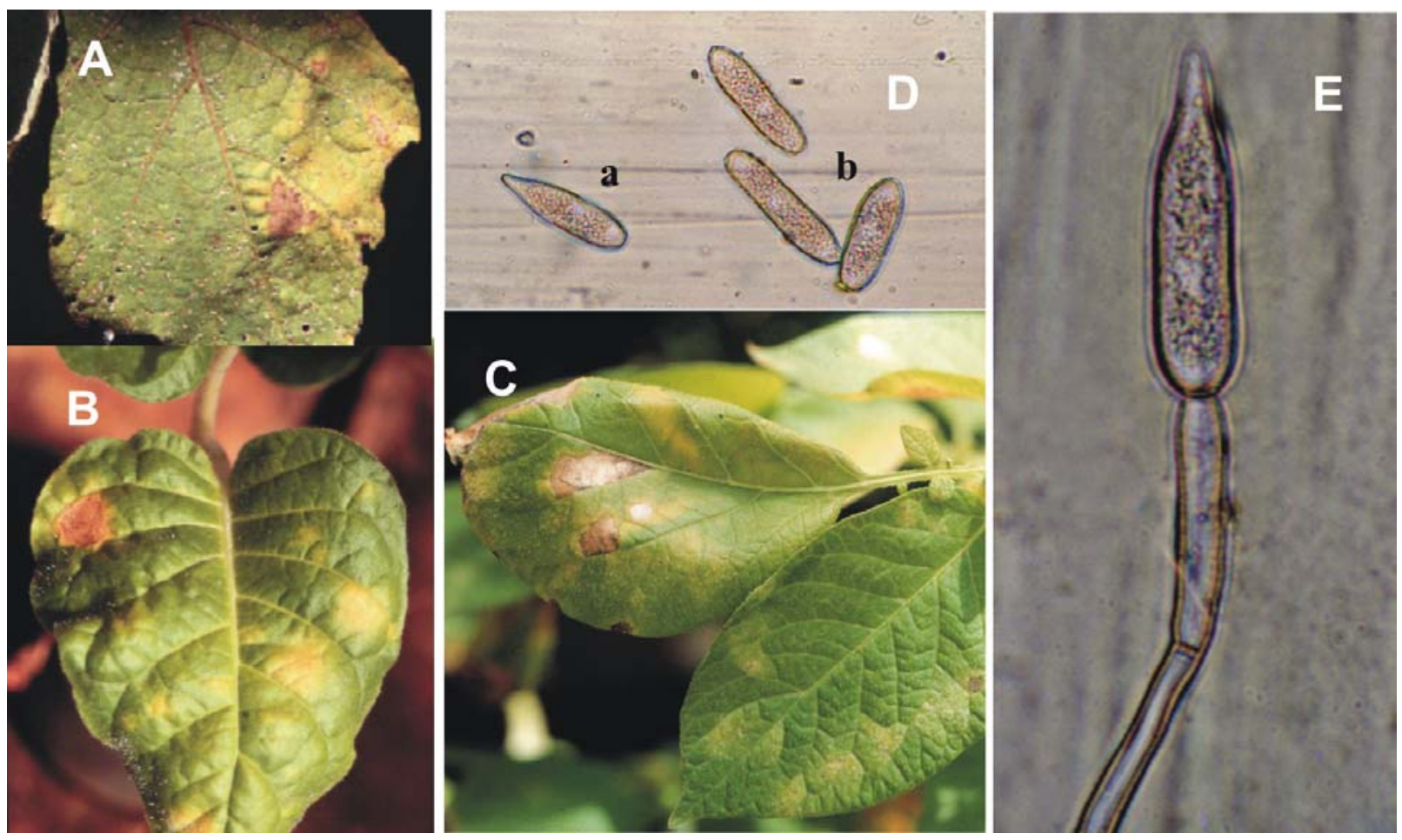

FIG. 1 - Powdery mildew symptoms caused by Oidiopsis haplophylli isolates on eggplant (Solanum melongena), (A); Nicotiana rustica (B); and potato (S. tuberosum) (C); morphological aspects of primary (a) and secondary (b) conidia of $O$. haplophylli obtained from infected gilo (S. gilo) leaves (D) and conidiophore with a terminal primary conidium (E). 
New hosts of Oidiopsis haplophylli in the Solanaceae family in Brazil

TABLE 1 - Length and diameter of primary and secondary conidia of Oidiopsis haplophylli from seven hosts of the Solanaceae family

\begin{tabular}{|c|c|c|c|c|}
\hline \multirow{2}{*}{ Host } & \multicolumn{2}{|c|}{ Primary Conidia* } & \multicolumn{2}{|c|}{ "Secondary conidia* } \\
\hline & Range & Average & Range & Average \\
\hline Capsicun annuun (standard) & $60,5-76,4 \times 13,7-19,4$ & $67,0 \times 15,6$ & $58,4-71,2 \times 13,3-19,6$ & $65,4 \times 15,8$ \\
\hline Nicotiana rustica & $49,8-73,1 \times 14,3-20,5$ & $60,1 \times 16,2$ & $55,9-71,3 \times 15,0-17,9$ & $64,8 \times 15,7$ \\
\hline N. tabacum & $54,1-71,0 \times 12,8-18,2$ & $65,3 \times 16,2$ & $53,8-71,7 \times 13,7-19,3$ & $63,2 \times 15,7$ \\
\hline Solanum chacoense & $59,6-76,6 \times 13,8-19,5$ & $67,1 \times 14,9$ & $56,8-70,3 \times 13,8-18,7$ & $65,1 \times 15,2$ \\
\hline S. gilo & $54,4-71,2 \times 12,6-18,9$ & $66,9 \times 15,3$ & $53,7-71,6 \times 13,1-19,2$ & $64,1 \times 15,8$ \\
\hline S. melongena & $36,0-78,5 \times 9,5-21,4$ & $66,3 \times 15,8$ & $31,8-68,5 \times 8,7-17,9$ & $65,0 \times 15,8$ \\
\hline S. tuberosum & $60,6-77,5 \times 13,5-19,6$ & $67,2 \times 15,5$ & $55,6-71,9 \times 13,3-19,5$ & $64,1 \times 15,8$ \\
\hline
\end{tabular}

*Length and diameter, measured in $\mu \mathrm{m}$

investigation plus one $O$. haplophylli isolate of sweet pepper employed as standard (Table 1). Primary and secondary conidia of the potato isolate were on average of $67.2 \mu \mathrm{m}$ long $\times 15.5 \mu \mathrm{m}$ diameter and $64.0 \mu \mathrm{m} \times 15.8 \mu \mathrm{m}$, respectively, whereas the isolates from eggplant were on average $66.3 \mu \mathrm{m} \times 15.8 \mu \mathrm{m}$ and $65.0 \mu \mathrm{m} \times 15.8 \mu \mathrm{m}$, respectively. The size of primary and secondary conidia from gilo were very close to that of potato and eggplant, $66.9 \mu \mathrm{m}$ long x $15.3 \mu \mathrm{m}$ diameter and [64.1 $\mu \mathrm{m} \times 15.8 \mu \mathrm{m}]$ and also very similar to that of $S$. chacoense, $67.1 \mu \mathrm{m}$ long $\mathrm{x} 14.9$ $\mu \mathrm{m}$ diameter and $65.1 \mu \mathrm{m} \times 15.2 \mu \mathrm{m}, N$. rustica $[60.1 \mathrm{x}$ 16.2] and [64.8 $\times 15.7]$, and $N$. tabacum [65.3 x 16.2] and [63.2 x 15.7]. The measurements taken from primary and secondary conidia of the original $O$. haplophylli isolate from sweet pepper cv. Margarita were in the following range: [67.0 $\mu \mathrm{m}$ long x $15.6 \mu \mathrm{m}$ diameter] and [65.4 $\mu \mathrm{m} \times 15.8 \mu \mathrm{m}]$, respectively. All these morphometrical characteristics were in the range reported for O. haplophylli (Yarwood, 1978; Boesewinkel, 1980; Braun, 1987; Cook et al., 1997; Liberato et al., 1998 and 2000).

Host range studies were conducted by inoculating plants either via dusting dry conidia or by leaf-to-leaf contact. The inoculum was obtained from each new host and individually placed on sweet pepper ('Margarita') and tomato ('Santa Clara') plants. Plants inoculated with each isolate were kept in separate growing chambers after inoculation. The presence of PM symptoms was assessed 15 days after inoculation. The results confirmed that $O$. haplophylli isolates from these new host species are pathogenic to sweet pepper and tomato. The pattern of symptom development was similar to that of $O$. haplophylli, characterized by chlorotic spots on the upper leaf surface that gradually turned to light brown necrotic lesions (Figure 1-A to C ).

Our report confirms that $O$. haplophylli has an unusual host range plasticity being able to infect a large number of plant species from genetically unrelated plant taxa (Braun, 1987; Mendes et al., 1998; Palti, 1988; Café Filho et al., 2001; Silva et al., 2003; Souza \& Café Filho, 2003). The host range of $O$. haplophylli appears to be broadening in Brazil without any strong evidence of host specialization (Café Filho et al., 2001; Paz Lima, et al. 2002; Silva et al., 2003; Souza \& Café Filho, 2003). Previous work by Souza \& Café Filho
(2003) demonstrated that $O$. haplophylli could be pathogenic to gilo and egg plant when artificially inoculated. However, our report is apparently the first formal description of these solanaceous species as natural hosts of $O$. haplophylli in Brazil. On the other hand, this is not the first record of a PM disease on potato in Brazil. Erysiphe cichoracearum De Candolle -like isolates have been previously reported infecting some $S$. tuberosum cultivars under greenhouse conditions (Boiteux, 1994). There is so far no report in the literature describing $N$. tabacum and $S$. chacoense as hosts of $O$. haplophylli. These new PM diseases caused by $O$. haplophylli may become important to these solanaceous crops especially under plastic house cultivation and/or in hot and dry areas where drip irrigation is employed.

\section{LITERATURE CITED}

BOESEWINKEL H.J. The morphology of the imperfect states of powdery mildews (Erysiphaceae). The Botanical Review 46:167224. 1980.

BOITEUX, L.S. Powdery mildew of potato caused by Erysiphe cichoracearum in Brazil. Plant Disease 78:830. 1994. (Note)

BOITEUX, L.S., SANTOS, J.R.M. \& LOPES, C.A. First record of powdery mildew of sweet-pepper (Capsicum annuum) incited by Leveillula taurica in Brazil. Fitopatologia Brasileira 19:304. 1994. (Resumo)

BRAUN, U. A monograph of the Erysiphales (powdery mildews). Nova Hedwigia. 89:1-700. 1987.

CAFÉ FILHO, A.C., COELHO, M.V.S. \& SOUZA, V.L. Oídios de Hortaliças. In: Stadnik, M.J. \& Rivera, M.C. (Eds.) Oídios. Jaguariúna: Embrapa Meio Ambiente, 2001. Cap. 11, pp.285-302.

COOK R.T.A., INMAN A.J. \& BILLINGS C. Identification and classification of powdery mildew anamorphs using light and scanning electron microscopy and host range data. Mycological Research 101:975-1002. 1997.

DOGANLAR, S., FRARY, A., DUANAY, M-C., LESTER, R.N. \& TANKSLEY, S.D. A comparative genetic linkage map of eggplant (Solanum melongena) and its implications for genome evolution in the Solanaceae. Genetics 161:1697-1711. 2002.

LIBERATO, J.R. LOURO, R.P., SUZUKI, M.S. \& BARRETO, R.W. Ocorrência de oídio do tomateiro causado por Oidiopsis no Estado do Rio de Janeiro. Fitopatologia Brasileira 23:81. 1998. (Abstract) 
LIBERATO, J.R. CUNHA, M., SUZUKI, M.S. \& SILVEIRA, S.F. Ocorrência do oídio do pimentão causado por Oidiopsis sp. no Estado do Espírito Santo. Fitopatologia Brasileira 25:110. 2000. (Abstract)

MENDES, M.A.S., SILVA, V.L., DIANESE, J.C., FERREIRA, M.A.S.V., SANTOS, C.E.N., GOMES NETO, E., URBEN, A.F. \& CASTRO, C. Fungos em plantas no Brasil. Brasília, Embrapa-SPI, Embrapa Cenargen, 1998.

PALTI, J. The Leveillula mildews. The Botanical Review 54:423535. 1988.

PAZ LIMA, M.L., BOITEUX, L.S., REIS, A., COSTA, S.B. \& LOPES, C.A. Alho porró: Hospedeiro de Oidiopsis taurica no Brasil. Fitopatologia Brasileira 27:S126. 2002. (Abstract)

SANTOS, J.R.M.\& BOITEUX L.S. Ocorrência de oídio (Leveillula taurica e Erysiphe cichoracearum) em tomateiro no Distrito Federal.
Fitopatologia Brasileira 19:313. 1994. (Abstract)

SILVA, P.P., LOPES, C.A., REIS, A., PAZ LIMA, M.L. \& BOITEUX, L.S. Eryngium foetidum, Petroselinum crispum, Coriandrum sativum e Solanum tuberosum: Novas hospedeiras de Oidiopsis taurica no Brasil. Fitopatologia Brasileira 28:S214. 2003. (Abstract).

SOUZA, V.L. \& CAFÉ FILHO, A.C. Genetic resistance to Leveillula taurica in the genus Capsicum. Plant Pathology 52:613619. 2003.

YARWOOD, C.E. History and taxonomy. In: Spencer, D.M. (Eds.) The Powdery Mildews. London:Academic Press, 1978. Cap.1, pp.128.

ZAMBOLIM, L., VALE, F.X.R. \& COSTA, H. Controle de doenças de plantas: hortaliças. Viçosa:Universidade Federal de Viçosa, 2000. 